\title{
Tarik Ulur Kompetensi Absolut Lembaga Arbitrase (Kajian Terhadap Prinsip Niet van Openbaar Orde dan Pacta Sunt Servanda Dalam Klausul Arbitrase)
}

\author{
Ayu Atika Dewi \\ Faculty of Law, Universitas Islam Indonesia, Indonesia \\ 164100101@uii.ac.id
}

Submitted: 2018-02-27; Reviewed: 2018-03-13; Accepted: 2018-04-23

\begin{abstract}
Arbitration is an institution of dispute settlement based on arbitration agreements. An arbitration agreement may be an arbitration clause incorporated by a standing agreement or an arbitral agreement independent of its principal agreement. Based on the arbitration agreement, there are two principles named Niet van Openbaar Order and Pacta Sunt Servanda. Based on the principle of the arbitration clause of the Niet van Openbaar Order, the arbitration clause does not necessarily provide the competence of the arbitration body to resolve the dispute under arbitration agreements. Instead the principle of clause is Pacta Sunt Servanda provides absolute competence for the arbitration body to resolve the dispute. The existence of these two principles leads to a lack of interpretation of the absolute competence of arbitration among law practitioners. This study aims to find out how exactly the competence of arbitration institutions in settling disputes that have been bound arbitration agreement is based on the duality principle of Niet van Openbaar Order and Pacta Sunt Servanda arbitration clause in Indonesian law. The results of the study explained that the legislation in the legal system of Indonesia as stipulated in Law no. 30 of 1999 has expressly stated that absolute competence for arbitration institution as the institution of dispute settlement which is bound by arbitration agreement. Therefore, the legal practitioners should return to the legal norm in order not to happen again the tug of competence to adjudicate disputes between the arbitration institution and the court institution. With this it is expected that the legal certainty in the arbitration order can be enforced.
\end{abstract}

Keywords: Arbitration agreement, Niet van Openbaar Order, Pacta Sunt Servanda.

\section{PENDAHULUAN}

Dewasa kini perkembangan bisnis dalam suasana kompetisi global telah mengarah pada free trade dan free competition.
Transaksi bisnis dalam era borderless membutuhkan perlindungan untuk menunjang kinerjanya. Perlindungan tersebut termasuk dalam hal penyelesaian sengketa. 
Bentuk penyelesaian sengketa yang lazim dikenal dan dipergunakan masyarakat adalah penyelesaian sengketa melalui pengadilan. Namun di mata pelaku bisnis, penyelesaian sengketa di pengadilan dipandang kurang cocok dengan iklim bisnis. Bagi pelaku bisnis, penyelesaian sengketa bisnis di pengadilan seringkali menimbulkan permasalahan. ${ }^{1}$ Tahap penyelesaian sengketa di pengadilan mengenal beberapa tingkatan, dimulai dari tingkat Pengadilan Negeri, Pengadilan Tinggi hingga kasasi dan peninjauan kembali di Mahkamah Agung. Hal ini menyebabkan proses beracara menjadi panjang dan lama. Panjang dan lamanya proses penyelesaian sengketa di pengadilan membawa implikasi pada tingginya biaya yang harus dikeluarkan (legal cost).

Beracara di pengadilan juga harus dilakukan dalam persidangan terbuka untuk umum. Padahal kerahasiaan suatu permasalahan merupakan hal penting bagi dunia bisnis. Disamping itu, pemeriksaan perkara di pengadilan seringkali dilakukan oleh hakim-hakim yang kurang menguasai substansi permasalahan perkara. Dalam banyak hal negara belum begitu cukup memiliki hakim-hakim yang memiliki kemampuan atau berkompetensi dalam spesialisasi hukum komersial (bisnis). ${ }^{2}$ Tentunya hal ini akan berpengaruh pada kualitas putusan yang dihasilkan.

Pada umumnya masyarakat bisnis menginginkan penyelesaian sengketa yang murah, cepat dan sederhana. Penyelesaian

\footnotetext{
${ }^{1}$ Moch. Basarah, Prosedur Alternatif Penyelesaian Sengketa Arbitrase Tradisional dan Modern (Online), Cetakan Pertama, Yogyakarta: Genta Publishing, 2011, hlm. 40

${ }^{2}$ Peter Schlosser, "What is International in the Legal Basis of International Arbitration", Comparative Law Review, Vol. XIX, No. 5, 1985, hlm 115.
}

sengketa bisnis dengan ciri moving quickly menuntut cara-cara yang informal procedure and be put in motion quickly. ${ }^{3}$ Sistem litigasi dengan formalitasnya sudah barang tentu tidak mampu mengimbangi ciri moving quickly tersebut. Dalam kondisi ini, dunia bisnis membutuhkan siklus penyelesaian sengketa baru yang lebih sesuai untuk menggeser peran litigasi. ${ }^{4}$ Siklus baru dalam penyelesaian sengketa binis tersebut kemudian dikenal dengan arbitrase.

Menurut Frank Elkouri dan Edna Elkouri ${ }^{5}$ dalam bukunya How Arbitration Works, arbitrase merupakan suatu proses mudah yang dipilih para pihak secara sukarela yang ingin agar perkaranya diputus oleh jurusita yang netral sesuai dengan pilhan mereka, dimana putusan tersebut didasarkan pada dalil-dalil dalam perkara yang ada, para pihak setuju sejak semula untuk menerima putusan secara final dan mengikat. Proses arbitrase dilakukan seperti proses beracara di pengadilan, hanya dengan prosedur lebih sederhana sesuai dengan kesepakatan para pihak.

Bagi dunia bisnis, penyelesaian sengketa lewat arbitrase atau perwasitan memiliki beberapa keunggulan. Seperti yang disampaikan oleh Prof. Subekti, penyelesaian sengketa bisnis melalui arbitrase dapat dilakukan dengan cepat, oleh para ahli dan secara rahasia. Arti penting arbitrase (peradilan wasit) bagi dunia bisnis juga diungkapkan oleh HMN

\footnotetext{
${ }^{3}$ M. Yahya Harahap, Beberapa Tinjauan Mengenai Sistem Peradilan dan Penyelesaian Sengketa, Bandung: Citra Aditya Bakti, 1997, hlm. 280-281.

${ }^{4}$ Susanti Adi Nugroho, Mediasi Sebagai Alternatif Penyelesaian Sengketa, Edisi Pertama, Jakarta: Telaga Ilmu Indonesia, 2009, hlm. 10.

5 Subekti, Arbitrase Perdagangan, Bandung: Angkasa Offset, 1981, hlm. 1.
} 
Purwosutjipto yakni pertama, penyelesaian sengketa melalui arbitrase dapat dilaksanakan dengan cepat. Kedua, parawasit (arbiter) terdiri dari orang-orang ahli dalam bidang yang disengketakan, yang diharapkan mampu membuat putusan yang memuaskan para pihak. Ketiga, putusan yang dibuat oleh arbiter yang ahli dianggap lebih sesuai dengan perasaan keadilan para pihak. Dan keempat, putusan peradilan wasit (arbitrase) dirahasiakan sehingga khalayak umum tidak mengetahui tentang kelemahan-kelemahan perusahaan yang bersangkutan. Sifat kerahasiaan ini lah yang dikehendaki oleh para pelaku bisnis.

Secara umum, keunggulan penyelesaian sengketa melalui arbitrase juga dapat dilihat dalam Penjelasan Umum UU No. 30 Tahun 1999 tentang Arbitrase dan Alternatif Penyelesaian Sengketa. Dalam penjelasan umum tersebut disebutkan bahwa keunggulan penyelesaian sengketa melalui arbitrase dibandingkan dengan lembaga peradilan ialah:

a. Terjaminnya kerahasiaan sengketa para pihak;

b. Keterlambatan yang diakibatkan hal prosedural dan administratif (seperti dalam penyelesaian lewat peradilan) dapat dihindari;

c. Para pihak dapat memilih arbiter yang berpengalaman, memiliki latar belakang yang cukup mengenai masalah yang dipersengketakan, serta jujur dan adil;

\footnotetext{
${ }^{6}$ Andi Julia Cakra, Penerapan Konsep Hukum Arbitrase Online di Indonesia, Yogyakarta: Rangkang Education, 2015, hlm. 174.
}

d. Para pihak dapat memilih tempat penyelenggaraan arbitrase;

e. Putusan arbitrase merupakan putusan yang mengikat para pihak serta dapat langsung dilaksanakan.

Melihat beberapa keunggulan tersebut, tidak heran jika para pebisnis berpaling dari pilihan penyelesaian sengketa di pengadilan ke lembaga arbitrase.

Arbitration is a bussines executive's court, ${ }^{6}$ begitu pendapat yang disepakati pelaku bisnis. Karakteristik penyelesaian sengketa lewat arbitrase yang relatif tidak terlalu formal dan sifat putusannya yang final and binding menjadi daya tarik para pebisnis. Arbitrase lebih banyak dipilih karena penyelesaian sengketa lewat pengadilan dianggap kurang mengakomodir kepentingan mereka. Prosedur penyelesaian yang panjang dan berbelit-belit menjadikan penyelesaian sengketa lewat institusi pengadilan membutuhkan waktu lama dan menghabiskan biaya. Hal ini tentunya dipandang tidak sejalan dengan iklim dunia bisnis yang menginginkan segala sesuatunya berlangsung dengan cepat dan efisien.

Dengan semakin meningkatkan transaksi bisnis di dunia, kehadiran lembaga arbitrase sebagai pranata penyelesaian sengketa di luar peradilan menjadi sebuah keniscayaan. Penyelesaian sengketa melalui arbitrase makin populer, terlebih apabila sengketa itu melibatkan pihak-pihak antar negara atau internasional. Dalam hukum internasional, penyelesaian sengketa secara damai adalah 
hal prinsip sebagaimana dinyatakan DJ. Harris berikut ini:

"It is a principle of international law that states shall settle their international disputes by peaceful means and not by resort force. This principle is reinforced by Article 33 U.N. Charter and the 1982 Manila Declaration on Peaceful Settlement of International Disputes. In international relations, most disputes are setteld throught negotiation between the parties assistence in the form of good offices, conciliation on the conduct of fact-finding inquiries." 7

Bagi dunia peradilan kehadiran lembaga arbitrase juga memiliki implikasi penting terkait kinerja aparat teknis pengadilan. Dengan berkembangnya praktek arbitrase dan cara-cara penyelesaian sengketa di luar peradilan akan mengurangi jumlah perkara yang masuk ke pengadilan. Hal ini pada gilirannya akan mengurangi beban perkara di pengadilan dan pada akhirnya akan berimbas pada efektifitas majelis hakim dalam memeriksa dan memutus perkara, karena dengan sedikitnya perkara majelis hakim akan lebih berkonsentrasi dalam menghadapi perkara di pengadilan. ${ }^{8}$

Pranata arbitrase dapat dipilih sebagai alternatif penyelesaian sengketa apabila sebelumnya para pihak telah bersepakat tentang pemilihan forum tersebut dalam kesepakatan tertulis. Kesepakatan tertulis tentang arbitrase dapat berupa klausula arbitrase ataupun perjanjian arbitrase. Klausula atau perjanjian arbitrase menjadi dasar untuk dapat dipergunakannya

\footnotetext{
${ }^{7}$ D.J. Harris, Cases and Materiale on International Law, Fifth Edition, London: Sweet Maxwell, 1998, hlm. 945.
}

arbitrase sebagai forum penyelesaian sengketa bagi para pihak. Oleh karena itu, jika perjanjian arbitrase tidak disepakati terlebih dahulu, maka suatu sengketa tidak dapat diselesaikan melalui arbitrase.

Dalam Pasal 1 butir (3) UU No. 30 Tahun 1999 disebutkan pengertian tentang perjanjian arbitrase sebagai suatu kesepakatan berupa klausula arbitrase yang tercantum dalam suatu perjanjian tertulis yang dibuat para pihak sebelum timbul sengketa, atau suatu perjanjian arbitrase tersendiri yang dibuat para pihak setelah timbul sengketa. Klausula arbitrase yang dibuat sebelum timbulnya sengketa lazim disebut dengan pactum de compromittendo sedangkan yang dibuat setelah sengketa disebut dengan akta kompromis. Baik pactum de compromittendo maupun akta kompromis sama-sama memiliki kekuatan mengikat sebagai dasar penyelesaian sengketa melalui arbitrase. Perbedaan diantara keduanya hanya mengenai waktu pembuatannya saja.

Menurut Pasal 11 UU No. 30 Tahun 1999 adanya perjanjian arbitrase meniadakan hak para pihak untuk mengajukan penyelesaian sengketa atau beda pendapat yang termuat di perjanjian ke pengadilan. Pengadilan dengan sendirinya menjadi tidak berwenang untuk mengadili sengketa para pihak yang telah terikat perjanjian arbitrase. Pengadilan wajib menolak dan tidak ikut campur tangan dalam suatu penyelesaian sengketa yang telah ditetapkan melalui arbitrase, kecuali dalam hal-hal tertentu yang ditetapkan undang-undang. Dengan demikian perjanjian arbitrase pada

\footnotetext{
${ }^{8}$ Suyud Margono, Alternatif Penyelesaian Sengketa \& Arbitrase: Proses Pelembagaan dan Aspek Hukum, Jakarta: Ghalia Indonesia, 2000, hlm. 9.
} 
prinsipnya memberikan kewenangan absolut kepada lembaga arbitrase untuk menyelesaikan sengketa atau beda pendapat para pihak yang penyelesaiannya telah disepakati menggunakan lembaga arbitrase.

Konsep hukum bahwa arbitrase sebagai bentuk alternatif penyelesaian sengketa memiliki kompetensi absolut yang berada di luar kewenangan pengadilan ternyata senantiasa menghadapi batu sandungan. ${ }^{9}$ Banyak perjanjian yang memuat klausula arbitrase seringkali diabaikan oleh pengadilan. Hal ini membawa konsekuensi bahwa pengadilan juga berwenang menangani sengketa yang sudah diserahkan kewenangannya ke lembaga arbitrase. Bahkan Mahkamah Agung dalam Putusan No. 1593K/ Pdt/ 2003 menjatuhkan putusan yang menafikan keberadaan lembaga arbitrase sebagai pranata penyelesaian sengketa. Majelis hakim dalam pertimbangan hukumnya menyatakan:

"Bahwa alasan ini pun dapat dibenarkan, oleh karena penyelesaian melalui arbitrase hanya merupakan alternatif yang dibolehkan oleh UU No. 4 Tahun 2004, tetapi bukan keharusan karena menurut ketentuan Pasal 10 ayat (2) UU No. 4 Tahun 2004 hanya dikenal empat lingkungan peradilan dan tidak termasuk badan arbitrase."

Di Indonesia, terdapat beberapa kasus yang meskipun sudah memiliki klausul arbitrase tetapi penyelesaian perkaranya tetap bergulir di pengadilan. Seperti dalam kasus Bankers Trust Company dan Bankers Trust International PLC (BT) melawan PT Mayora Indah Tbk (Mayora), PN Jakarta
Selatan tetap menerima gugatan Mayora sekalipun ada klausul arbitrase didalamnya dan menjatuhkan putusan No.46/Pdt.G/1999 tanggal 9 Desember 1999, yang memenangkan Mayora. Di sisi lain perkara ini sudah diputus oleh Mahkamah Arbitrase London dan diajukan pelaksanaannya ke PN Jakarta Pusat oleh BT. Ketua PN Jakarta Pusat dalam putusannya No. 001 dan 002/Pdt/Arb.Int/1999/PN.JKT.PST juncto 02/Pdt.P/2000/PNJKT.PST, tanggal 3 Februari 2000, menolak permohonan BT bagi pelaksanaan putusan Arbitrase London, dengan alasan pelanggaran ketertiban umum. Pelanggaran ketertiban umum yang dimaksud adalah bahwa perkara tersebut masih dalam proses peradilan (di PN Jakarta Selatan) dan belum memiliki kekuatan hukum tetap. Penolakan PN Jakarta Pusat tersebut dikuatkan oleh Putusan Mahkamah Agung melalui putusan Nomor 02 K/Ex'r/Arb.Int/Pdt/2000 tanggal 5 September 2000.

Selain itu ada kasus antara PT. Fega Indotama dan LVMH Fragrances \& Cosmetics Pte. Ltd. Singapore. Antara kedua pihak tersebut terikat Perjanjian Distribusi Eksklusif tertanggal 10 Juli 2009 yang berlaku selama tiga tahun. Perjanjian tersebut memberikan hak tunggal dan eksklusif untuk mengimpor, mendistribusikan dan menjual produkproduk parfum feminim dan maskulin, jenis-jenis produk make up dan perawatan kulit dengan merek LVMH Fragrances \& Cosmetics dan parfum Christian Dior untuk seluruh wilayah Indonesia dengan Surat

9 Gunawan Widjaja, Arbitrase VS. Pengadilan: Persoalan Kompetensi (Absolut) Yang Tidak Pernah Selesai, Jakarta: Kencana, 2008, hlm. 1. 
Tanda Pendaftaran Distributor Tunggal Barang Produksi Luar Negeri Nomor 2788/STP-LN/PDN.2/8/2011 yang berlaku hingga 2 Mei 2013. Dalam kontrak tersebut termuat klausula arbitrase, yakni:

"Any disputes or differences arising out of or in connection with this contract, including any question regarding its existence, validity or termination, shall be refered to and finally resolved by arbitration in Singapore in accordance with the Arbitration Rules of Singapore International Centre (SIAC Rules) for the time being in force, which rules are deemed to be incorporated by reference to this clause."

Namun meskipun dalam kontrak tersebut telah termuat klausula arbitrase, proses penyelesaian atas perkara tersebut tetap bergulir di pengadilan karena PT. Fega Indotama (Penggugat) mengajukan perkara tersebut melalui PN Jakarta Pusat dengan dalil perbuatan melawan hukum karena LVMH Fragrances \& Cosmetics Pte. Ltd. Singapore (Tergugat) telah memutuskan kontrak.

Kasus lain yang masih segar diingatan ialah perjanjian penanaman saham oleh Hary Tanoe Soedibjo kepada PT. Cipta Televisi Pendidikan Indonesia yang pada saat itu saham terbanyaknya dimiliki oleh Siti Hardianti Rukmana. Dalam perjanjian investasi tersebut telah disepakati bahwa apabila dalam pelaksanaan perjanjian ditemui permasalahan antara para pihak, maka untuk menyelesaikannya akan ditempuh melalui jalur arbitrase sebagaimana diatur dalam Pasal 13.2, Pasal 13.3 dan Pasal 13.4 Investment Agreement. Perkara ini telah diselesaikan melalui lembaga arbitrase BANI dan BANI juga

${ }^{10}$ M. Yahya Harahap, Arbitrase, Jakarta: Pustaka Kartini, 1991, hlm. 124. telah mengeluarkan putusan. Namun perkara tersebut tetap bergulir di pengadilan karena pihak Siti Hardianti Rukmana mengajukan gugatan atas Hary Tanoe Soedibjo ke PN Jakarta Pusat dan PN Jakarta Pusat menerima gugatan tersebut.

Kenyataan mengenai tarik ulur kompetensi absolut lembaga arbitrase atas perkara yang telah disepakati perjanjian arbitrase tidak dapat dilepaskan dari keberadaan ada dua prinsip tentang kekuatan berlakunya perjanjian arbitrase dalam kaitannya dengan kompetensi absolut yang dilahirkan dari perjanjian tersebut. Prinsip-prinsip yang dimaksud dijabarkan sebagai berikut.

1. Aliran yang mengajarkan bahwa perjanjian arbitrase bukan publik order atau bukan kepentingan umum (niet van openbaar orde). ${ }^{10}$ Menurut aliran ini, adanya perjanjian arbitrase tidak mutlak menyingkirkan kewenangan pengadilan untuk menyelesaikan perkara yang timbul dari perjanjian. Oleh karena itu meskipun dengan adanya perjanjian arbitrase, pengadilan tetap berwenang menyelesaikan sengketa jika salah satu pihak mengajukan sengketa tersebut ke pengadilan. Dalam hal ini perjanjian arbitrase hanya memberi opsi atau hak pilih bagi para pihak untuk menyelesaikan sengketa lewat arbitrase atau pengadilan. Jika salah satu pihak mengajukan penyelesaian sengketa ke arbitrase maka baru gugur kewenangan yang dimiliki pengadilan untuk menyelesaikan sengketa para pihak. 
Namun jika salah satu pihak mengajukan sengketa ke pengadilan, dengan sendirinya gugur kewenangan arbitrase untuk menyelesaikan sengketa para pihak.

2. Aliran yang mengajarkan bahwa perjanjian arbitrase didasarkan pada prinsip pacta sunt servanda.

Aliran ini mengajarkan bahwa perjanjian arbitrase sifatnya mengikat para pihak dan hanya dapat dikesampingkan dengan kesepakatan bersama yang tegas untuk itu. ${ }^{11}$ Adanya perjanjian arbitrase menurut prinsip pacta sunt servanda secara mutlak menyingkirkan kewenangan pengadilan untuk menyelesaikan sengketa. Perjanjian arbitrase secara otomatis memberikan kompetensi absolut bagi lembaga arbitrase untuk menyelesaikan sengketa para pihak yang terikat perjanjian arbitrase. Penarikan secara sepihak dalam hal ini tidak bisa dipakai untuk menafikan kompetensi absolut lembaga arbitrase tersebut.

Berdasarkan latar belakang tersebut, penulis tertarik untuk mengkaji tentang judul Tarik Ulur Kompetensi Absolut Lembaga Arbitrase (Kajian Terhadap Aliran Niet van Openbaar Orde dan Pacta Sunt Servanda Dalam Klausul Arbitrase) dengan mengambil permasalahan bagaimana sebenarnya kompetensi lembaga arbitrase dalam menyelesaikan sengketa yang telah terikat perjanjian arbitrase didasarkan pada dualisme aliran

11 Bambang Sutiyoso, Penyelesaian Sengketa Bisnis, Yogyakarta: Citra Media, 2006, hlm. 56.
Niet van Openbaar Orde dan Pacta Sunt Servanda klausul arbitrase dalam tata hukum Indonesia?.

\section{PEMBAHASAN}

Kompetensi Absolut Lembaga Arbitrase berdasarkan Prinsip Niet Van Openbaar Orde dan Pacta Sun Servarda dalam Klausul Arbitrase di Sistem Hukum Indonesia

Perkembangan arbitrase dimulai sejak dilahirkannya Jay Treaty pada tahun 1794 oleh Amerika dan Inggris. Treaty tersebut bertujuan untuk menyelesaikan sengketa dagang yang terjadi diantara warga negara mereka. Sebelum Jay Treaty dibuat, penyelesaian sengketa dagang dilakukan melalui sistem saluran diplomatik. Namun sistem tersebut dinilai mengecewakan karena penyelesaiannya cenderung dipengaruhi kepentingan politik. Dengan dilahirkannya Jay Treaty, cara penyelesaian yang berkarakter politik digeser ke arah model penyelesaian yang berkarakter hukum. Hal tersebut dilakukan dengan membentuk institusi baru bernama mixed commission yang bertugas menyelesaikan sengketa dagang secara hukum. Mixed commission kemudian berkembang dan menjadi cikal bakal arbitrase nasional dan internasional, dimana masing-masing negara mengakuinya sebagai extra judicial, penyelesaian sengketa dilakukan berdasarkan rule yang disepakati, putusan langsung final and binding, serta putusan dapat dipaksakan eksekusinya oleh pengadilan dan yurisdiksinya hanya terbatas pada sengketa dagang. ${ }^{12}$

\footnotetext{
${ }^{12}$ Susanti Adi Nugroho, Mediasi Sebagai Alternatif Penyelesaian Sengketa, Edisi Pertama, Jakarta: Telaga Ilmu Indonesia, 2009, hlm. 9.
} 
Di Indonesia sendiri, perkembangan arbitrase telah cukup lama dikenal dengan pengaturan yang terdapat dalam Pasal 307 HIR/ 705 RBg. Pasal 307 HIR berbunyi: "Jika orang Indonesia dan orang Timur Asing menghendaki perselisihan mereka diputuskan oleh juru pisah, maka mereka wajib menuruti peraturan pengadilan perkara yang berlaku bagi bangsa Eropa." Ketentuan tersebut memberikan kemungkinan bagi para pihak untuk menyerahkan penyelesaian perselisihan mereka melalui juru pisah (arbitrase) apabila dikehendaki demikian. Namun sayangnya, Pasal 307 HIR/ 705 RBg tidak mengatur lebih lanjut tentang mekanisme penyelesaian perselisihan melalui juru pisah ini. Oleh karena itu untuk mengisi kekosongan aturan tentang arbitrase, Pasal 307 HIR/ 705 RBg menunjuk aturan-aturan arbitrase yang terdapat dalam $\mathrm{Rv}$ (Reglemen Hukum Acara Perdata) sebagai aturan umum tentang arbitrase. ${ }^{13}$ Aturan tersebut termaktub dalam Pasal 615-651 Rv. ${ }^{14}$

Seiring dengan berkembangnya waktu, aturan-aturan tentang arbitrase yang ada dalam Rv dirasa sudah tidak mampu mengakomodir perkembangan hukum arbitrase itu sendiri. Oleh karenanya pada tahun 1999 pemerintah mengeluarkan kebijakan baru di bidang penyelesaian sengketa dengan menerbitkan UU No. 30 Tahun 1999 tentang Arbitrase dan

\footnotetext{
${ }^{13}$ M. Yahya Harahap, Arbitrase, Jakarta: Pustaka Kartini , 1991, hlm. 22.

${ }^{14}$ Aturan umum arbitrase dalam Rv terbagi dalam lima bagian pokok, yaitu:

1. Bagian Pertama (Pasal 615 - 623) mengatur tentang persetujuan arbitrase dan pengangkatan arbitrator atau arbiter;

2. Bagian Kedua (Pasal 624 - 630) mengatur tentang pemeriksaan di muka badan arbitrase;
}

Alternatif Penyelesaian Sengketa. Dengan adanya undang-undang tersebut, segala peraturan tentang arbitrase yang berlaku sebelumnya dinyatakan tidak berlaku lagi.

Arbitrase adalah cara penyelesaian sengketa perdata di luar pengadilan umum yang didasarkan pada perjanjian arbitrase yang dibuat secara tertulis oleh para pihak yang bersengketa (Pasal 1 angka 1 UU No. 30 Tahun 1999 tentang Arbitrase dan Alternatif Penyelesaian Sengketa). Dalam definisi tersebut dapat diketahui jika perjanjian arbitrase menjadi dasar bagi penyelesaian sengketa para pihak melalui arbitrase. Sebagai sebuah perjanjian, kekuatan mengikat perjanjian arbitrase digantungkan pada syarat-syarat keabsahan perjanjian pada umumnya berdasarkan Pasal 1320 KUH Perdata. Pasal tersebut menyebutkan bahwa syahnya suatu perjanjian harus memenuhi empat syarat, yaitu:

1. Adanya kesepakatan para pihak;

2. Kecakapan para pihak dalam melakukan perbuatan hukum;

3. Kesepakatan mengenai hal tertentu;

4. Objek dari kesepakatan harus mengenai sebab yang halal.

Keempat syarat tersebut kemudian dikelompokkan menjadi dua, yaitu syarat subjektif dan syarat objektif.

1. Syarat subjektif

3. Bagian Ketiga (Pasal 631 - 640) mengatur tentang putusan arbitrase;

4. Bagian Keempat ( Pasal 641 - 647) mengatur tentang upaya-upaya terhadap putusan arbitrase;

5. Bagian Kelima (Pasal 647- 651) mengatur tentang berakhirnya acara-acara arbitrase. 
Syarat subjektif berkaitan dengan subjek perjanjian. Subjek dalam perjanjian arbitrase sama dengan perjanjian pokoknya yang dapat terdiri dari: $:^{15}$ a) orang-perorangan; b) badanbadan hukum; c) lembaga/ organisasi pemerintah dan negara. Dalam perjanjian arbitrase, para pihak yang bersengketa harus terlebih dahulu membuat kesepakatan tentang penggunaan arbitrase sebagai forum penyelesaian sengketa.

Kesepakatan tentang arbitrase apabila ditinjau dari UU No. 30 Tahun 1999 dapat dilihat dalam ketentuan Pasal 7 yang berbunyi "Para pihak dapat menyetujui sengketa yang terjadi diantara mereka diselesaikan melalui arbtrase." Kata menyetujui dalam ketentuan tersebut menunjukkan bahwa suatu sengketa hanya dapat diselesaikan melalui arbitrase apabila sebelumnya telah sama-sama disetujui oleh para pihak. Dengan kata lain, apabila tidak disetujui sebelumnya maka sengketa tersebut tidak dapat diselesaikan melalui arbitrase. Kata menyetujui dalam Pasal 7 apabila dikaitkan dengan Pasal 9 UU No. 30 Tahun 1999 maka persetujuan tersebut harus dibuat dalam bentuk tertulis. ${ }^{16}$ Berikut adalah bunyi Pasal 9 UU No. 30 Tahun 1999, yaitu:

a. Dalam hal para pihak memilih penyelesaian sengketa melalui arbitrase setelah sengketa terjadi, persetujuan mengenai hal tersebut harus dibuat dalam

\footnotetext{
${ }^{15}$ Sudiarto dan Zaeni Asyhadie, Mengenal Arbitrase Salah Satu Alternatif Penyelesaian Sengketa Bisnis, Cetakan Ke-1, Jakarta: Raja Grafindo Persada, 2004, hlm. 65.
}

suatu perjanjian tertulis yang ditandatangani oleh para pihak.

b. Dalam hal para pihak tidak dapat menandatangani perjanjian tertulis sebagaimana dimaksud dalam ayat (1), perjanjian tertulis tersebut harus dibuat dalam bentuk akta notaris.

c. Perjanjian tertulis sebagaimana dimaksud dalam ayat (1) harus memuat:

1) masalah yang dipersengketakan;

2) nama lengkap dan tempat tinggal para pihak;

3) nama lengkap dan tempat tinggal arbiter atau majelis arbitrase;

4) tempat arbiter atau majelis arbitrase akan mengambil keputusan;

5) nama lengkap sekretaris;

6) jangka waktu penyelesaian sengketa;

7) pernyataan kesediaan dari arbiter; dan

8) pernyataan kesediaan dari pihak yang bersengketa untuk menanggung segala biaya yang diperlukan untuk penyelesaian sengketa melalui arbitrase.

\section{Syarat Objektif}

Syarat objektif berkaitan dengan objek dari perjanjian. Objek dalam perjanjian arbitrase diatur dalam Pasal

${ }^{16}$ Suleman Batubara dan Orinton Purba, Arbitrase Internasional: Penyelesaian Sengketa Investasi Asing Melalui ICSID, UNCITRAL Dan SIAC, Jakarta: Raih Asa Sukses, 2013, hlm. 26. 
5 ayat (1) UU No. 30 Tahun 1999, yang menyatakan bahwa:

"Sengketa yang dapat diselesaikan melalui arbitrase hanya sengketa di bidang perdagangan dan mengenai hak yang menurut hukum dan peraturan perundang-undangan dikuasai sepenuhnya oleh pihak yang bersengketa."

Pengertian perdagangan dalam pasal tersebut dapat dilihat dalam Penjelasan Pasal 66 huruf b UU No. 30 Tahun 1999 yang menyebutkan bahwa sengketa-sengketa yang dapat menjadi objek arbitrase adalah sengketa dalam ruang lingkup hukum perdagangan yaitu kegiatan-kegiatan di bidang:

a. Perniagaan;

b. Perbankan;

c. Keuangan;

d. Penanaman modal;

e. Industri; dan

f. Hak kekayaan intelektual.

Dari sini dapat diketahui jika objek arbitrase ialah sengketa di bidang perdagangan dan sengketa yang menurut peraturan perundangundangan tidak dapat diadakan perdamaian. Secara logis jika objek dalam klausula atau perjanjian arbitrase di luar ruang lingkup bidang-bidang tersebut maka perjanjian itu dapat dikatakan batal demi hukum.

Para pihak dapat menyetujui perjanjian suatu sengketa yang terjadi atau yang akan terjadi diantara mereka untuk diselesaikan melalui arbitrase dengan perjanjian tertulis yang disepakati para pihak (Pasal 7 UU No. 30 Tahun 1999 tentang Arbitrase dan Alternatif Penyelesaian Sengketa). Adanya perjanjian tertulis tersebut meniadakan hak para pihak untuk mengajukan penyelesaian sengketa atau beda pendapatnya ke pengadilan. Pengadilan juga seharusnya menghormati perjanjian tersebut dengan menyatakan diri tidak berwenang mengadili sengketa yang sebelumnya telah terikat perjanjian arbitrase. Namun dalam praktek, seringkali perjanjian yang memuat klausula arbitrase diabaikan oleh pengadilan. Terbukti dengan masih adanya proses pengadilan atas sengketa yang telah terikat perjanjian arbitrase.

Proses pengadilan terhadap kasus yang terikat perjanjian arbitrase dapat dilihat salah satunya dalam kasus Investment Agreement antara Hary Tanoe Soedibjo melawan Siti Hardianti Rukmana. Dalam perjanjian tersebut telah disepakati bahwa terjadinya sengketa memuat klausul arbitrase sebagai alternatif penyelesaian sengketa. Klausula arbitrase dalam perjanjian tersebut termuat dalam:

Pasal 13 (1) "Segala sengketa yang timbul diantara Para pihak yang berasal dari atau terkait dengan Perjanjian ini, termasuk tetapi tidak terbatas pada, pertanyaan apapun terkait dengan penafsiran, keabsahan pelaksanaan, keefektifan dan pemutusan hak atau kewajiban dari pihak manapun akan diselesaikan secara musyawarah";

Pasal 13.3 "Apabila sengketa tersebut tidak dapat diselesaikan dengan musyawarah oleh Para pihak, maka sengketa tersebut harus 
diselesaikan secara eksklusif dan bersifat final melalui arbitrase di Jakarta menurut Peraturan Badan Arbitrase Nasional Indonesia";

Pasal 13.4 "Pasal 13 ini merupakan suatu Klausula Arbitrase yang tercakup dalam pengertian menurut Undang Undang Nomor 30 Tahun 1999 tentang Arbitrase dan Alternatif Penyelesaian Sengketa (12 Agustus 1999) dan tidak dapat dicabut serta mengikat Para Pihak untuk menyerahkan sengketa kepada arbitrase bersifat final dan mengikat sesuai dengan hukum dan ketentuanketentuan di dalam Perjanjian ini”;

Kenyataan tarik ulur kompetensi absolut arbitrase terhadap perkara yang terikat perjanjian arbitrase tidak dapat dipisahkan dari eksistensi teori tentang kekuatan mengikat perjanjian arbitrase yang memunculkan kompetensi absolut arbitrase tersebut. Teorinya ialah sebagai berikut.

1. Aliran yang mengajarkan bahwa perjanjian arbitrase bukan publik order atau bukan kepentingan umum (niet van openbaar orde). ${ }^{17}$

Menurut aliran ini, adanya perjanjian arbitrase tidak mutlak menyingkirkan kewenangan pengadilan untuk menyelesaikan perkara yang timbul dari perjanjian. Oleh karena itu meskipun dengan adanya perjanjian arbitrase, pengadilan tetap berwenang menyelesaikan sengketa jika salah satu pihak mengajukan sengketa tersebut ke pengadilan. Dalam hal ini perjanjian arbitrase hanya memberi opsi atau hak pilih bagi para pihak untuk menyelesaikan sengketa lewat arbitrase atau pengadilan. Jika salah satu pihak mengajukan penyelesaian sengketa ke arbitrase maka baru gugur kewenangan yang dimiliki pengadilan untuk menyelesaikan sengketa para pihak. Namun jika salah satu pihak mengajukan sengketa ke pengadilan, dengan sendirinya gugur kewenangan arbitrase untuk menyelesaikan sengketa para pihak.

2. Aliran yang mengajarkan bahwa perjanjian arbitrase didasarkan pada prinsip pacta sunt servanda.

Aliran ini mengajarkan bahwa perjanjian arbitrase sifatnya mengikat para pihak dan hanya dapat dikesampingkan dengan kesepakatan bersama yang tegas untuk itu. ${ }^{18}$ Adanya perjanjian arbitrase menurut prinsip pacta sunt servanda secara mutlak menyingkirkan kewenangan pengadilan untuk menyelesaikan sengketa. Perjanjian arbitrase secara otomatis memberikan kompetensi absolut bagi lembaga arbitrase untuk menyelesaikan sengketa para pihak yang terikat perjanjian arbitrase. Penarikan secara sepihak dalam hal ini tidak bisa dipakai untuk menafikan kompetensi absolut lembaga arbitrase tersebut.

Eksistensi kedua teori tersebut berimplikasi pada beragamnya sikap pengadilan (hakim) dalam memaknai kompetensi absolut arbitrase yang lahir dari perjanjian arbitrase. Hakim yang menganut

\footnotetext{
${ }^{17}$ M. Yahya Harahap, Arbitrase, Op.cit, hlm. 124.

${ }^{18}$ Bambang Sutiyoso, Op.cit. hlm. 56.
} 
aliran pertama yang memaknai perjanjian arbitrase bukan publik order atau bukan kepentingan umum (niet van openbaar orde memandang perjanjian arbitrase tidak mutlak memberikan kompetensi absolut bagi arbitrase untuk menyelesaikan sengketa para pihak. Jika dilihat dalam praktek peradilan di Indonesia, pandangan ini masih banyak dijadikan acuan oleh hakim-hakim pengadilan. Terbukti dengan masih adanya pengadilan yang menerima perkara yang terikat perjanjian arbitrase seperti pada kasus investment agreement antara Hary Tanoesoedibjo melawan Siti Hardianti Rukmana (PT. Cipta Televisi Pendidikan Indonesia) diatas.

Perkara lain yang menunjukkan masih dianutnya prinsip klausula arbitrase tidak mutlak menyingkirkan kompetensi absolut arbitrase adalah kasus Bankers Trust Company dan Bankers Trust International PLC (BT) melawan PT Mayora Indah Tbk (Mayora). Dalam kasus yang telah terikat klausula arbitrase tersebut, PN Jakarta Selatan tetap menerima gugatan Mayora dan menjatuhkan putusan No.46/Pdt.G/1999 tanggal 9 Desember 1999 yang memenangkan Mayora. Ketua PN Jakarta Pusat dalam Putusan No.001 dan 002/Pdt/Arb.Int/1999/PN.JKT.PST juncto Putusan No. 02/Pdt.P/2000/PNJKT.PST tanggal 3 Februari 2000 menolak permohonan BT bagi pelaksanaan putusan Arbitrase London, dengan alasan pelanggaran ketertiban umum, pelanggaran ketertiban umum yang dimaksud adalah bahwa perkara tersebut masih dalam proses peradilan dan belum memiliki kekuatan hukum tetap. Penolakan PN Jakarta Pusat tersebut dikuatkan oleh Putusan

\footnotetext{
${ }^{19}$ Ibid, hlm. 125.
}

Mahkamah Agung No.02 K/Ex'r/Arb.Int/Pdt/2000 tanggal 5 September 2000.

Dikalangan praktisi hukum, dianutnya pandangan klausula arbitrase tidak mutlak menyingkirkan kompetensi absolut arbitrase disebabkan karena sebelum berlakunya UU No. 30 Tahun 1999, Rv sebagai landasan umum tentang arbitrase tidak memberi penegasan yang pasti tentang hal itu. ${ }^{19}$ Pasal 615 ayat $1 \mathrm{Rv}$ hanya menjelaskan tentang kebolehan para pihak untuk menyerahkan penyelesaian atau pemutusan sengketa ke arbitrase. Sedangkan penegasan apakah kewenangan tersebut mutlak atau tidak, tidak dijelaskan lebih lanjut. Akibatnya terjadi kesimpangsiuran dalam praktek penyelesaian perkara yang terikat perjanjian arbitrase. Banyak kasus yang terikat perjanjian arbitrase diajukan ke pengadilan dan pengadilan tetap memeriksa perkara tersebut. Sampai pada akhir tahun 1990 masih banyak hakim di pengadilan tingkat pertama yang berpendapat bahwa klausula arbitrase tidak menggugurkan secara mutlak kewenangan pengadilan. $^{20}$

Hal ini dapat dilihat misalnya dalam kasus PT. United Tractor melawan PT Intan Cemerlang yang diputus oleh Mahkamah Agung dengan putusan tanggal 4 Mei 1988 No. 3179 K/Pdt/1984. Dalam putusan tersebut majelis hakim berpendapat bahwa:

"Klausula arbitrase yang tercantum dalam pasal 21 Surat Perjanjian hanya merupakan formalitas. Lagi pula ada adagium bahwa penyelesaian sengketa melalui arbitrase belum dapat menyelesaikan sebagaimana yang

${ }^{20}$ Ibid, hlm. 126. 
diharapkan. Dengan demikian, meskipun ada klausula arbitrase pengadilan tetap berwenang memeriksa dan mengadili sengketa yang timbul dari perjanjian."

Kasus lain dapat dilihat dalam perkara asuransi yang berdasar pada perjanjian standar yang memuat klausul arbitrase antara Ny. Tan Tio Sardono melawan PT. Prescopy Insurance Company Ltd yang diselesaikan oleh PN Jakarta Pusat. Dalam putusannya tanggal 4 Juni 1986 No.512/Pdt/G/1985, hakim menimbang bahwa:

"Klausula arbitrase a quo merupakan pactum de compromittendo yang sesuai dengan perkembangan hukum baru, menurut pendapat majelis dewasa ini tidak dapat dibenarkan untuk perkara asuransi, terutama in casu, karena perkara ini tidak sekedar quantum dan tanggung gugat yang tidak dipermasalahkan, melainkan tanggung gugat itu sendiri yang bersifat yuridis benar. Karena poli a quo merupakan perjanjian standar yang dirumuskan sepihak oleh penanggung, penafsiran ketentuan-ketentuan termasuk klausula arbitrasenya harus dilakukan contra preferenten (Pasal 1349 KUH Perdata). Selain dari itu, klausula arbitrase a quo adalah kabur dan tidak jelas sehingga membuka peluang bagi suatu pihak untuk mengulur waktu mengenai pengangkatan arbiter dan dengan demikian melawan asas peradilan sederhana, cepat dan biaya ringan. Sebaliknya klausula arbitrase a quo mengandung diskriminasi karena apabila penanggung hendak melancarkan tindakan hukum, maka tindakan hukum tersebut akan melalui pengadilan sedangkan lain pihak, hak tersebut tidak diberikan kepada tertanggung.

Menurut majelis, penggungat menjadi beneficiary strooman belaka dalam klaim asuransi a quo. Kasus a quo berkaitan dengan tindak pidana dan karenanya menyangkut soal ketertiban umum (public orde) sehingga pada hakikatnya perkara a quo tidak boleh dijamah arbitrase dan klausula arbitrase a quo tidak dapat mencakupinya sehingga perkara a quo harus diperiksa dan diadili oleh pengadilan."

Dalam contoh kasus-kasus diatas, praktek peradilan masih menunjukkan kebimbangan dalam menafsirkan ketentuan Pasal 615 ayat (1) Rv. Hal ini dapat dipahami karena penegasan tentang kompetensi absolut arbitrase yang menyingkirkan kewenangan pengadilan dalam menyelesaikan perkara yang terikat kesepakatan arbitrase tidak disebutkan dengan tegas. Namun dalam UU No. 30 Tahun 1999 pengaturan tentang kompetensi absolut arbitrase yang secara otomatis menyingkirkan pengadilan telah diatur dengan tegas. Pengaturan tersebut dapat dilihat dalam Pasal 11 UU No. 30 Tahun 1999 yang menyatakan bahwa:

1) Adanya suatu perjanjian arbitrase tertulis meniadakan hak para pihak untuk mengajukan penyelesaian sengketa atau beda pendapat yang termuat dalam perjanjiannya ke Pengadilan Negeri.

2) Pengadilan Negeri wajib menolak dan tidak akan campur tangan di dalam suatu penyelesaian sengketa yang telah ditetapkan melalui 
arbitase, kecuali dalam hal-hal tertentu yang ditetapkan dalam Undang-undang ini.

Dengan adanya pengaturan dalam Pasal 11 diatas, pandangan yang menganggap bahwa klausula arbitrase bukan public order (niet van openbaar orde) seharusnya tidak dibenarkan lagi. Pandangan yang menganggap bahwa perjanjian arbitrase tidak mutlak menyingkirkan kompetensi pengadilan atas perkara yang terikat perjanjian arbitrase tidak sejalan dengan norma dalam UU No. 30 Tahun 1999. Dalam undang-undang tersebut telah mengatur secara tegas kompetensi absolut arbitrase atas perkara yang telah terikat perjanjian arbitrase. Hal ini tidak hanya ditegaskan dalam Pasal 11 saja namun juga ditegaskan dalam Pasal 3 UU No. 30 Tahun 1999 berikut:

"Pengadilan Negeri tidak berwenang untuk mengadili sengketa para pihak yang telah terikat dalam perjanjian arbitrase."

Jika dilihat norma dalam UU No. 30 Tahun 1999 tentang kompetensi absolut arbitrase sebagaimana diatur dalam Pasal 3 dan Pasal 11 diatas, jelas bahwa undangundang tersebut menganut prinsip klausula arbitrase merupakan pacta sunt servanda. Asas pacta sunt servanda membawa implikasi bahwa semua kesepakatan yang dibuat para pihak secara sah, berlaku sebagai undang-undang bagi yang membuatnya, oleh karenanya para pihak harus menjalankan kesepakatan tersebut dengan itikat baik. Dalam hal ini penarikan secara sepihak tidak dibenarkan berdasarkan asas pacta sunt servanda.
Penarikan kesepakatan dapat dilakukan hanya apabila kedua belah pihak setuju untuk mengakhiri kesepakatan tersebut.

Asas pacta sunt servanda dituangkan dalam Pasal 1338 KUH Perdata yang berbunyi:

1) Semua persetujuan yang dibuat secara sah sesuai dengan undangundang berlaku sebagai undangundang bagi mereka yang membuatnya.

2) Persetujuan itu tidak dapat ditarik kembali selain dengan kesepakatan kedua belah pihak atau karena alasan yang ditentukan oleh undang-undang.

3) Persetujuan harus dilaksanakan dengan itikat baik.

Jika makna pacta sunt servanda dalam Pasal 1338 KUH Perdata dikaitkan dengan perjanjian arbitrase, maka terdapat beberapa asas untuk diterapkan terkait kompetensi absolut arbitrase. Acuan penerapannya ialah: ${ }^{21}$

1) Setiap perjanjian arbitrase secara mutlak mengikat para pihak dan kekuatan mengikatnya serupa dengan kekuatan undang-undang;

2) Oleh karena itu, apabila timbul persengketaan dari apa yang diperjanjikan para pihak, maka kewenangan untuk menyelesaikan dan memutus sengketa tersebut mutlak menjadi kewenangan lembaga arbitrase;

3) Dengan demikian, pengadilan menjadi tidak berwenang memeriksa dan mengadili sengketa para pihak yang sudah disepakati perjanjian arbitrase; 
4) Gugurnya klausula hanya terjadi apabila secara tegas ditarik kembali atas kesepakatan para pihak;

5) Dan tidak dapat dibenarkan penarikan secara diam-diam apalagi penarikan secara sepihak.

Berdasarkan penjabaran diatas dapat diketahui bahwa pandangan yang menganggap klausula arbitrase merupakan pacta sunt servanda sangat bertentangan dengan pandangan yang menganggap klausula arbitrase bukan public order (niet van openbaar orde). Dalam pandangan klausula arbitrase bukan public order (niet van openbaar orde) penarikan secara diamdiam bahkan penarikan secara sepihak dengan mengajukan gugatan ke pengadilan dibenarkan. Tidak demikian dalam pandangan yang menganggap klausula arbitrase merupakan pacta sunt servanda. Dalam pandangan ini adanya perjanjian arbitrase melahirkan kompetensi absolut lembaga arbitrase dan secara otomatis menyingkirkan kewenangan pengadilan untuk memeriksa perkara para pihak yang terikat perjanjian arbitrase.

Berdasarkan pengamatan praktek pengadilan di Indonesia, aliran pacta sunt servanda dianut dan dipegangi oleh sebagian besar putusan tingkat kasasi, sedangkan aliran niet van openbaar orde dianut oleh sebagian putusan pengadilan tingkat pertama dan tingkat banding. ${ }^{22}$ Sikap Mahkamah Agung yang menonjolkan aliran pacta sunt servanda dapat dilihat dalam beberapa kasus yang diputus oleh Mahkamah Agung berikut:

1) Putusan Mahkaman Agung tanggal 22 Februari 1982, dalam perkara Ahyu Foresty Company Limited, yang menyatakan bahwa dalam hal adanya klausula arbitrase, Pengadilan Negeri tidak berwenang.

2) Putusan Mahkamah Agung No. $1371 \mathrm{~K} / \mathrm{Pdt} / 1989$ tertanggal 29 Juni 1995 dalam perkara Yacobs Busono lawan Banque Francaise $\mathrm{Du}$ Commerce Exteriur dan Areliers Allibe \& C.I.E, dipertimbangkan :

“..... keberatan-keberatan ini dapat dibenarkan karena Judex facti telah melanggar tata cara mengadili yang ditentukan oleh Undang-undang seperti yang ditegaskan dalam pasal 3 (1) Undang-undang No.14 tahun 1970 yang dipertegas lagi dengan Yurisprudensi tetap yang memberi wewenang absolut kepada arbitrase penyelesaian sengketa yang timbul dari perjanjian apabila daam perjanjian termuat klausul arbitrase.

Bahwa ternyata dalam perjanjian tanggal 23 April 1982 terdapat klausul arbitrase dalam pasal 10 . Begitu juga dalam perjanjian tanggal 15 September 1982 dalam pasal 9 ada kesepakatan klausula arbitrase.

Bahwa berdasarkan fakta-fakta tersebut para pihak telah sepakat secara pactum de compremittendo, bahwa penyelesaian sengketa yang timbul dari perjanjian harus diselesaikan oleh lembaga arbitrase. Berati sejak semula para pihak telah sepakat menyingkirkan kewenangan pengadilan untuk menyelesaikan sengketa yang timbul dari perjanjian untuk

${ }^{22}$ Ibid, hlm. 130. 
menyelesaikan sengketa yang timbul daari perjanjian dan sepenuhnya secara absolut jatuh menjadi kewenangan arbitrase sesuai dengan yang digariskan dalam penjelasaan pasal 3 (1) Undang-Undang No.14 tahun 1970".

3) Putusan Mahkamah Agung dalam perkara antara PT. Asuransi Hastin dengan PT. Pool Asuransi Indonesia.

Pengadilan Negeri Jakarta Utara yang mengadili perkara tersebut di tingkat pertama, menyatakan diri tidak berwenang atas perkara tersebut karena dalam Polis Kebakaran yang disepakati kedua belah pihak dalam Pasal XXI ditentukan apabila terjadi perselisihan akan diselesaikan oleh arbitrase. Putusan tersebu kemudian dibatalkan oleh Pengadilan Tinggi DKI Jakarta melalui putusannya tertanggal 14 Oktober 1997 No. 558/Pdt/1997/PT.DKI dengan menyatakan bahwa PN Jakarta Utara berwenang untuk memeriksa perkara tersebut dan memerintahkan PN Jakarta Utara untuk memeriksa pokok perkara. Pada tingkat kasasi, putusan Pengadilan Tinggi DKI Jakarta dibatalkan oleh Mahkamah Agung melalui putusan No. 3942 K/Pdt/1999 tanggal 10 September 1999 dengan pertimbangan bahwa ada klausula arbitrase dalam Polis Kebakaran yang disepakati para pihak.

${ }^{23}$ Sudargo Gautama, Hukum Dagang dan Arbitrase Internasional, Bandung: Citra Aditya Bakti, 1999, hlm. 297-301.
Dari putusan-putusan diatas dapat diketahui jika bahkan sebelum diterbitkannya UU No. 30 Tahun 1999, pengakuan terhadap klausul arbitrase sebagai pacta sunt servanda yang memberikan kompetensi absolut arbitrase bagi perkara yang terikat perjanjian arbitrase itu sudah diakui. Padahal Rv sendiri sebagai aturan main dalam perarbitrasean pada masa itu belum memberikan aturan yang tegas tentang kompetensi absolut lembaga arbitrase yang menyingkirkan kewenangan pengadilan bagi perkara arbitrase tersebut. Mahkamah Agung bahkan sebelum berlakunya UU No. 30 Tahun 1999 telah mengakui dengan jelas eksistensi kompetensi absolut arbitrase dengan dikeluarkannya putusan yang membatalkan berbagai putusan pada tingkat judex factie yang menyatakan kewenangan mengadili terhadap sengketa yang dalam perjanjian pokonya mengandung klausula arbitrase. ${ }^{23}$ Aliran niet van openbaar orde nampaknya mengalami hambatan untuk berkembang karena sebagian putusan yang diberikan berdasarkan aliran ini akan dimentahkan di pemeriksaan kasasi. $^{24}$

Namun menjadi aneh ketika praktek pengadilan pasca dikeluarkannya UU No. 30 Tahun 1999 justru menafikan ketentuan tentang kompetensi absolut lembaga arbitrase. Padahal secara hukum telah jelas bahwa Pengadilan Negeri tidak berwenang untuk mengadili sengketa para pihak yang telah terikat dalam perjanjian arbitrase sebagaimana diatur dalam Pasal 3 UndangUndang Nomor 30 Tahun 1999 tentang Arbitrase dan Alternatif Penyelesaian

\footnotetext{
${ }^{24}$ M. Yahya Harahap, Arbitrase, Op.cit.
} 
Sengketa. Berkaitan dengan hal tersebut Sudargo Gautama berpendapat bahwa:

"Bahwa jika ada klausula arbitrase maka pengadilan tidak dapat memeriksa perkara bersangkutan. Dalam intensi pertama pengadilan harus menyatakan diri tidak berwenang untuk memeriksa perkara tersebut dan menyerahkan kepada arbitrase. Oleh Mahkamah Agung Republik Indonesia sudah diakui hal ini. Dalam berbagai perkara yang akhir-akhir ini telah diputuskan, kita saksikan bahwa pengadilan di Indonesia umunya pada waktu sekarang ini dihormati klausula arbitrase. Jika terdapat klausula arbitrase ini maka pengadilan negeri akan menyatakan dirinya tidak berwenang untuk memeriksa perkara bersangkutan. Sikap demikian adalah sesuai dengan Konvensi New York 1958 yang berlaku di Indonesia sejak Keppres 1981 Nomor 334 (Pasal II ayat 3). ${ }^{.25}$

Dari penjelasan di atas dapat dipahami bahwa telah tertera dalam UU No. 30 Tahun 1999 bahwa Pengadilan Negeri tidak memiliki kewenangan terhadap perkara yang telah disepakati para pihak untuk diselesaikan melalui lembaga arbitrase. Pengadilan Negeri wajib menghormati lembaga arbitrase sebagai lembaga yang ditunjuk oleh undangundang untuk menyelesaikan sengketa yang telah ditugaskan padanya dan apabila terdapat pengajuan gugatan kepada Pengadilan Negeri mengenai sengketa yang telah disepakati untuk diselesaikan melalui lembaga arbitrase maka sangatlah berkekuatan hukum bagi Pengadilan Negeri untuk menolak perkara tersebut dan menyerahkan sepenuhnya penyelesaian sengketa melalui lembaga arbitrase.

Tarik ulur kompetensi absolut antara lembaga arbitrase dan pengadilan dapat pula disebabkan karena kaburnya pengaturan tentang penggunaan pranata arbitrase sebagai forum penyelesaian sengketa yang termuat baik dalam klausula maupun perjanjian arbitrase. Sebagian besar klausul arbitrase hanya menyatakan secara sederhana bahwa para pihak akan menggunakan arbitrase untuk semua sengketa yang timbul dari perjanjian. ${ }^{26} \mathrm{Hal}$ ini dapat menjadi kelemahan dari klausul arbitrase yang kemudian berakibat pada kaburnya kompetensi absolut arbitrase. Kelemahan klausul arbitrase adalah tidak diaturnya prosedur arbitrase secara rinci dan jelas.

Oleh karena itu, seharusnya klausul arbitrase dibuat dengan mengacu pada peraturan-peraturan spesifik tertentu dengan menunjuk pada prosedur arbitrase yang telah ada. Dengan hal tersebut, diharapkan hal-hal yang menyebabkan ketidakjelasan kompetensi arbitrase yang lahir dari klausula arbitrase dapat dihindari.

Berkaitan dengan hal ini dapat dipakai rumusan klausula arbitrase sebagaimana yang disarankan oleh berbagai arbitrase institusional yang ada. Seperti BANI yang menyarankan para pihak yang ingin menggunakan BANI untuk mencantumkan klausula standar berikut dalam perjanjian mereka.

"Semua sengketa yang timbul dari perjanjian ini, akan diselesaikan dan diputus oleh BANI menurut peraturanperaturan administrasi dan peraturan-

26 Gatot Soemartono, Arbitrase dan Mediasi di Indonesia, Jakarta: Gramedia Pustaka Utama, 2006, hlm. 150 . 
peraturan proseddur BANI, yang keputusannya mengikat kedua belah pihak yang bersengketa sebagai keputusan dalam tingkat pertama dan terakhir."

Atau mengikuti aturan dalam arbitrase internasional seperti dalam klausula arbitrase UNCITRAL berikut.

"Any disputes, controversy or claim arising out of relation to this contract, or the breach, termination in validity there of, shall be settled by arbitration in accordance with the UNCITRAL Arbitration Rules as set present in force. The appointing authority shall be the ICC acting in accodance with the rules adopted by the ICC for this purpose."

\section{PENUTUP}

Tarik ulur kompetensi absolut lembaga arbitrase tidak bisa dilepaskan dari eksistensi dua pandangan tentang klausul arbitrase yaitu prinsip yang memandang bahwa klausula arbitrase merupakan pacta sunt servanda dan prinsip yang memandang bahwa klausula arbitrase bukan public order (niet van openbaar orde). Prinsip yang memandang bahwa klausula arbitrase merupakan pacta sunt servanda secara mutlak memberikan kewenangan mengadili sengketa yang terikat perjanjian arbitrase pada lembaga arbitrase. Sebaliknya prinsip yang memandang bahwa klausula arbitrase bukan publik order (niet van openbaar orde) tidak secara mutlak memberikan kewenangan pada lembaga arbitrase.

Berkembangnya prinsip klausula arbitrase bukan public order (niet van openbaar orde) dilatarbelakangi oleh ketidakjelasan pengaturan tentang kompetensi absolut arbitrase dalam Pasal $615 \mathrm{Rv}$ ayat (1). Namun setelah dikeluarkannya UU No. 30 Tahun 1999, pengaturan tentang kompetensi absolut arbitrase telah ditegaskan dalam Pasal 3 dan Pasal 11 undang-undang tersebut. Norma yang terkandung dalam UU No. 30 Tahun 1999 menganut prinsip bahwa klausula arbitrase merupakan pacta sunt servanda yang secara mutlak memberikan kompetensi absolut bagi lembaga arbitrase bagi penyelesaian perkara yang terikat perjanjian arbitrase. Namun dalam prakteknya di kalangan hakim masih terdapat ketidakseragaman dalam memaknai Pasal 3 dan Pasal 11 UU No. 30 Tahun 1999 yang menyebabkan tarik ulur kompetensi absolut antara lembaga arbitrase dan lembaga pengadilan dalam memeriksa perkara yang terikat perjanjian arbitrase.

Berdasarkan kesimpulan diatas, penulis menyarankan agar untuk menuntaskan tarik ulur kompetensi absolut antara lembaga arbitrase dan lembaga pengadilan dalam memeriksa perkara yang terikat perjanjian arbitrase sebaiknya dikembalikan pada norma hukum yang mengatur tentang kompetensi absolut tersebut yaitu pada Pasal 3 dan Pasal 11 UU No. 30 Tahun 1999. Pengadilan dalam menyikapi perkara yang terikat perjanjian arbitrase semestinya berpedoman pada norma hukum yang ada. Selain itu diperlukan juga itikat baik dari para pihak untuk mematuhi norma hukum yang ada dengan tidak mengajukan perkara yang telah terikat perjanjian arbitrase ke pengadilan. Dengan begitu diharapkan fenomena tarik ulur kompetensi absolut ini dapat diminimalkan sehingga kepastian hukum penyelesaian sengketa melalui arbitrase dapat ditegakkan. 


\section{DAFTAR PUSTAKA}

Buku

Andi Julia Cakra, Penerapan Konsep Hukum Arbitrase Online di Indonesia, Yogyakarta: Rangkang Education, 2015.

Bambang Sutiyoso, Penyelesaian Sengketa Bisnis, Yogyakarta: Citra Media, 2006.

D.J. Harris, Cases and Materiale on International Law, Fifth Edition, London: Sweet Maxwell, 1998.

Gatot Soemartono, Arbitrase dan Mediasi di Indonesia, Jakarta: Gramedia Pustaka Utama, 2006.

Gunawan Widjaja, Arbitrase VS. Pengadilan: Persoalan Kompetensi (Absolut) Yang Tidak Pernah Selesai, Jakarta: Kencana, 2008.

Moch. Basarah, Prosedur Alternatif Penyelesaian Sengketa Arbitrase Tradisional dan Modern (Online), Cetakan Pertama, Yogyakarta: Genta Publishing, 2011.

M. Yahya Harahap, Beberapa Tinjauan Mengenai Sistem Peradilan dan Penyelesaian Sengketa, Bandung: Citra Aditya Bakti, 1997.

M. Yahya Harahap, Arbitrase, Jakarta: Pustaka Kartini, 1991.

Subekti, Arbitrase Perdagangan, Bandung:

Angkasa Offset, 1981.

Sudargo Gautama, Hukum Dagang dan

Arbitrase Internasional, Bandung:

Citra Aditya Bakti, 1999.

Sudiarto dan Zaeni Asyhadie, Mengenal

Arbitrase Salah Satu Alternatif Penyelesaian Sengketa Bisnis, Cetakan Ke-1, Jakarta: Raja Grafindo Persada, 2004.

Susanti Adi Nugroho, Mediasi Sebagai Alternatif Penyelesaian Sengketa,
Edisi Pertama, Jakarta: Telaga Ilmu Indonesia, 2009.

Suyud Margono, Alternatif Penyelesaian Sengketa \& Arbitrase: Proses Pelembagaan dan Aspek Hukum, Jakarta: Ghalia Indonesia, 2000.

\section{Jurnal}

Peter Schlosser, "What is International in the Legal Basis of International Arbitration", Comparative Law Review, Vol. XIX, No. 5, 1985.

\section{Peraturan Perundang-Undangan}

UU No. 30 Tahun 1999 tentang Arbitrase dan Alternatif Penyelesaian Sengketa.

UU No. 35 atahun 1999 jo. UU No. 14 Tahun 1970 jo. UU No. 14 Tahun 1985 tentang Ketentuan Pokok Kekuasaan Kehakiman.

UU No. 7 Tahun 1994 tentang Pengesahan Agreement Establishing World Trade Organization.

UU No. 5 Tahun 1968 tentang Pengesahan Convention of the Settlement of Investment disputes between State and Nationals of Other State (ICSID).

Herzien Inlandsch Reglement (HIR)

Reglement op de Rechtsvordering (Rv)

Keputusan Presiden No. 34 Tahun 1981 tentang Pengesahan Convention on the Recognition and Enforcement of Foreign Arbitral Award New York 1958.

Peraturan Mahkamah Agung RI No. 1 Tahun 1990 tentang Tata Cara Pelaksanaan Putusan Arbitrase Asing. 